\title{
The Development Status and Suggestions of Chinese Biological Medicine
}

\author{
Jin-guo WANG ${ }^{1}$ and $\mathrm{Na} \mathrm{WANG}^{2,{ }^{*}}$ \\ ${ }^{1}$ Department of Urology, The First Hospital of Jilin University, China \\ ${ }^{2}$ Department of Anesthesiology, The First Hospital of Jilin University, China \\ ${ }^{*}$ Corresponding author
}

Keywords: Biological Medicine, Biotechnology, Technology Trends.

\begin{abstract}
Biological medicine is listed on the country's important development strategy planning in the United States, the European Union, Japan and other major developed countries and some developing countries. Through analysis of Chinese current situation of the development of biological medicine and compared with abroad. We point out that the development opportunity and the feasible suggestions associated with the development of biological medicine. Domestic development of biological medicine should focus on independent research and development, set up efficient technology platform, select the appropriate development project and promote the development of enterprises on the base of the biological technologies transferred from developed countries.
\end{abstract}

\section{Introduction}

Since the first genetically engineered products in the United States, biological medicine has developed rapidly at abroad. Our country's enterprises, scientific research institutions and researchers tend to research independently, but it is the lack of use and integration of external resources to help their study effectively. On one hand, the government invested a lot of money to establish many foreign biomedical technology platforms of the services they can offer at all levels, but most of these platforms are difficult to provide effective assistance in Chinese market and public technology platform cannot play its function of social service and leading industry [1].

\section{The Development Situation of Biological Medicine Abroad}

\section{The Unbalanced Development of Biomedical Medicine Abroad}

The United States, the European Union and Japan were the main developed countries which are dominant in biological medicine. The United States is the most main force for biological medicine development. At the same time, the United States is the world's biggest consumer market of biomedicine. The national biotechnology industries in other countries are still mainly small and medium-sized enterprises which are generally less than 100 people and suffer the lack of similar international big companies. Research data display that in the enterprises of biological medicine, most of the companies are losing money and the whole biological medicine industry is not yet profitable [2]. 


\section{Innovation is Important for the Development of Biotechnology and Biological Medicine}

Innovation requires a big fortune on scientific researches and development of biological medicine. American medical enterprises invest about $15 \%$ of income to bring them a steady stream of new products, so enterprises' income is also rising.

\section{The Current Situation of Biological Medicine in China}

\section{Late Start and Rapid Development}

Domestic biotechnology and biological medicine appeared in the late 1980s, since the first biotech drug in 1989 when interferon was approved. The industry has developed rapidly with annual growth rate of more than two digits, which has been higher than the growth rate of the whole pharmaceutical industry.

\section{The Overall Competitiveness is Low}

Like the pharmaceutical industry, biological medicinal products almost have no independent intellectual property rights in our country, most of them are generic varieties and the lack of patent protection, resulting in a kind of biological medicine having more than $20 \sim 30$ companies to produce. The phenomenon of production causes severe overcapacity, intense industry competition and low profit and is unable to form the benign development. In addition to the first domestic product and first listed enterprise profit, the majority of enterprises can't make money out of it. Even in this medicine, domestic biological medicine industry is not successful and very few biological medicines can get annual output value of more than one hundred million yuan [3].

\section{Developed Countries Seldom Transfer Technologies}

Foreign biological pharmaceutical companies are active to get into the domestic market, mainly through direct importing product drugs. Raw material is the domestic main product sales. Biological medicine research and production need a large number of high skilled talents. Biological medicine industry produces less pollution. The cost gap of production in developed countries and the developing countries is not big. Biological medicine involves the core technology. Therefore, the biological medicine companies tend to keep the production secret to prevent the outflow of core technology. Especially in recent years, the United States and other developed countries strengthen the policies to prevent the leading technology to transfer to other countries [4]. Therefore, the development of domestic pharmaceutical enterprises can only base on our own research to set up our own core competitiveness.

\section{The Development Suggestions of Biological Medicine in Our Country}

\section{The Construction of Comprehensive Professional Services Firm of Biological Medicine}

Development of talents, technology assessment, technology trading services and comprehensive professional services are also important content of the construction of the biological medicine professional service system. The lack of talent is an important factor restricting the development of biological medicine industry [5]. For the vast majority of biological pharmaceutical enterprises in China, it is very difficult to bear the high of the cost of human resources to build and maintain biological medicine research and development on various aspects of scientific research team. The lack of talent and 
resources need to attract talents to make enterprises reach a high level of science and technology. We should formulate associated policies and flexible mechanism to attract overseas talents in biological medicine, actively introduce a large number of high level base-research-type talents, promote biomedical technology research and development in our country. Vigorously the introduction of open type biological medicinal products research and development talent can drive our biological pharmaceutical products from imitation to innovation [6].

\section{Talent Training}

Local talent cultivation plan include: cultivating talents engaged in all kinds of basic biomedical technology researches, including biology, medicine, pharmacy and information technology. Cultivating suitable talents for a biotechnology product development includes biological engineering and design personnel. The work of management talents with comprehensive quality includes biomedical strategic management, project management, human resource management and budget management, such as biological medicine, head of the business, enterprise, head of the biomedicine technology [7]. Cultivating talents engages in biomedical research, patent protection of intellectual property rights and patent application, such as a lawyer familiar with biological pharmaceutical technology and legal knowledge.

\section{The Cooperation with Research Institutions}

In large state-owned scientific research institutions and institutions of advanced education, we should focus on the most high level scientific research personnel in the field of biomedicine, including quite a few people out or between market demand and industry development scientific research work, which leads to a huge waste of our country's biological medicine resources [8].

The technical personnel have a clear understanding, a human resource database and communication network for biological medicine industry. The professional services firm helps and organizes companies to seek researchers as a technical consultant or project horizontal cooperation, in scientific research institutes, colleges and universities. It is one of the ways to solve the problem of talent for our biotechnology enterprises.

\section{Mechanism Transformation is Needed for Research Institutions}

In China, research institutes engaged in biomedicine are mainly attached to provinces and cities at various levels. These research institutes have a large number of scientific research projects, but these projects don't give priority to generic pharmaceutical companies and development level is not high. Mechanism of scientific research institutes need changes to dig new project implementation [9].

Most of domestic companies haven't get the core technology. The improvement of patent protection are urgent. For example, gene mutation is part of the company's products, the patent protection is the ideal way. If incremental improvement meets the following conditions, it does not reflected in the products, such as the mutation of the gene product is now leading products. It has been included in the previous patent.

\section{Summary}

Biological medicine industry abroad has developed rapidly in recent years in the developed world. Biological pharmaceutical products occupy an important position in the pharmaceutical market and mammalian cell expression products already occupy the main position of biological medicine. On the contrast, biological medicine industry in 
China mainly uses the simple expression of yeast, having technical difficulties of high mammalian cells.

On the base of the biological technologies transferred from developed countries, domestic development of biological medicine should focus on independent research and development, set up efficient technology platform, select the appropriate development project and promote the development of enterprises.

\section{References}

[1] Maskell P. Towards a knowledge-based theory of the geographical cluster. Industrial and Corporate Change. 2001

[2] Batavia Industrial Center. http://www.nystar.state.ny.us/incubators.htm.

[3] Covin JG, Slevin DP. A conceptual model of entrepreneurship as firm behavior. Entrepreneurship Theory and Practice. 1991

[4] Stina Gestrelius, Mikael Oerum. Cluster Formation as an Efficient Tool for High TechIndustry Development in the Innovation Driven Economy in the21st Century. www.mediconvalley.com.

[5] Oxfordshire Bioscience Network Oxfordshire Bioscience Cluster Report 2005. www.oxfordshire.uk.gov.

[6] Covin JG, Slevin DP. Strategic management of small firms in hostile and benign environments. Strategic Management Journal. 1989

[7] Shrivastava P. Environmental Technologies and Competitive Advantage. Strategic Management Journal. 1995

[8] Teece David J, Pisano Gary, Shuen Amy. Dynamic capabilities and strategic management. Strategic Management Journal. 1997

[9] Mintzberg H. Strategy-Making in Three Modes. California Management Review. 1973 